\title{
'Lock Her Up’: Harassment and Violence Against Women in Alberta Politics
}

\author{
By Meghan Cardy
}

\begin{abstract}
Since the 'Orange Wave' of the 2015 election in Alberta, women within and outside of the NDP caucus have experienced incredible levels of harassment from both ideological opposition and within their own parties. This harassment occurs towards the government demonstrative of the most success in formal representation women have ever had in Albertan politics. This uptick in the frequency and severity of harassment online, in protest, and in traditional political channels such as party leadership contests lead some to question the role Alberta's political culture played in it's occurrence, and the impact such a culture may have in the future. Examined using theory of gendered electoral violence and in the larger context of women's political leadership in Canada, this paper proposes that a further critical eye should be turned towards this phenomenon rather than including it as a part of the job of doing politics as a woman.
\end{abstract}

\section{Introduction}

Across Canada, women have been making strides in increasing representation in electoral politics and positions of political power. Along with this greater representation comes greater opportunity to examine the lived experience of women in Canadian politics, especially the way the experience of holding office can be shaped by the beliefs about gender within our political culture. Recent media coverage has highlighted numerous instances of often violent and misogynistic harassment directed towards female elected officials in Alberta, especially towards Premier Rachel Notley, members of her caucus, and female candidates in the race for leadership of the Progressive Conservative party. Premier Notley has even taken the title of the most threatened Albertan Premier on record (Trynacity 20I6). This then begs the questions: does this violence further dis-empower women in the political sphere, and what factors in Alberta's political environment contribute to this form of violence? In this paper I will make the argument that repeated instances of harassment along gendered lines in Albertan politics are symptomatic of a political culture which views female elected officials from positions of questioned legitimacy, thus motivating harassment and threats. I will examine how the online harassment, threats of harm, and critiques of suitability for office based on gendered criteria that are experienced by female elected officials in Alberta at an incredible level constitute a form of gendered political violence, which must not be considered under the umbrella of 'healthy discourse'. The examination of these issues is vital to the health of Albertan democracy, as the reality of this violence further discourages women from striving for equality within structures of power. Further, I will examine how these criticisms often focus on or threaten the legitimacy of a woman's authority. This trend may be fostered by the typical circumstances of a woman's election to a position of power in weakened parties or trying political climates, factors both shaping Albertan politics at the time of the most recent election.

\section{Gendered Electoral Violence}


Media attention has begun to discuss notable incidents of harassment experienced by women in Alberta's political sphere, and their incredible frequency and ferocity. An example of this can be found in the highly contested passing of Bill 6, a farm safety bill, due to which the women of the NDP caucus experienced considerable online harassment. The staggering number of threats of violence against various MLAs prompted comment in the legislature from Energy Minister Marg McCuaig-Boyd, who highlighted that "a climate has been created where people are afraid to speak" (Sharpe and Braid 20I6, I72). A report published in February of 2017 by Kim Trynacity of CBC examined the frequency of threats against Rachel Notley, who experienced $4 \mathrm{I} 2$ incidences of inappropriate contact and communication as compared to the 55 experienced by all other Premiers of Alberta from 2003 onward. When the records were limited to offline threats, as tracking of social media commenced only during Notley's leadership, she still had the highest incidence (nineteen), seconded closely by Allison Redford, the only other woman Premier in Alberta, with sixteen threats (Trynacity 20I7). These examples of harassment easily fall under the umbrella of gendered electoral violence, a phenomenon that occurs in nuanced ways and serves to discourage the participation of women in formal politics. Gabrielle Bardall defines this type of violence as “....any random or conspiratorial acts to discourage, suppress, or prevent women from exercising their electoral rights. This includes women's participation as voters, candidates, party supporters, election workers, observers, journalists, or public officials" $(2 \mathrm{OI} 3, \mathrm{I}-2)$. This definition perfectly encapsulates the danger of widespread harassment of women in politics, as even random instances in aggregate create an environment, as mentioned by McCuaigBoyd, wherein genuine political participation could be curtailed so as to prevent further personal consequences.

Declaring this harassment to be a real form of violence with an important political impact is a discursive shift that gives power to those who wish to remove barriers from women's participation. The abuse of women in politics is typically considered to be a symptom of a traditional belief that characteristics intrinsic to 'maleness' and 'femaleness' better suited men to public life and women to roles in the private sphere of the home. The harassment of politically active women discourages their participation to preserve this distinction (Krook 2OI7, 74-75). Accepting that this level of abuse is a natural part of political life denies that those unwilling to weather it are important political actors. Especially as this abuse occurs in the face of women's electoral success, "inhibiting female officeholders from fulfilling their duties strikes at the integrity of the electoral process and violates the rights to vote and to see democratic choices respected. Such actions, moreover, deprive citizens of exposure to full debate and to the contributions that women can make to solving society's problems" (75). Interestingly, when commenting on this online harassment during a 2OI5 press conference Notley displayed a reluctance to link it to Albertan political culture as a whole, but some argue that this served as a discursive strategy meant to quell tensions and is indicative of " a more female approach to power" (Sharpe and Braid 20I6, I75).

Bardall's work on the role of information and communication technologies in this violence demonstrates how gendered beliefs about politics are displayed in online harassment, an examination which resonates with the struggle of the women of the most recent NDP caucus and their leader, Rachel Notley. Bardall cites three important characteristics of online harassment that serve to disempower women specifically, namely that women are more susceptible to attacks on their morality due to their presence in a male-dominated field and the ensuing double standards, that social media presents an opportunity to engage in very personal harassment with very few consequences for the perpetrator, and the frightening speed with 
which abuse and discrimination can be disseminated and amplified through sharing and approval-based promotion (2OI3, 3-4). Bardall notes "...the speed and scope of social media attacks have a chilling effect on political aspirants, especially women entering politics for the first time. Women frequently cite the threat of widespread, rapid public attacks on personal dignity as a factor deterring women from entering politics" (4). Each of the aforementioned women in the legislature of Alberta continued their work in the face of this online harassment, but as is noted by Bardall, the most important impact may be seen before an election even occurs as candidates for office step forward, or decide to limit their own participation.

The impact of a culture of abuse and harassment present a challenge to equality of representation for women in formal politics, as it discourages potential participants who do not wish to endure this violence and therefore seek other means to be politically active. Studies examining the significant phenomenon of reduced political ambition amongst women - that is the desire to seek and hold elected office, point to the possibility that internalized beliefs about women's viability as candidates, the resulting lack of recruitment, and worries about the consequences of participation limit women's representation more than electoral failure due to sexism amongst the electorate (Lawless and Fox 20IO). Women's reluctance to face abuse is perhaps in their personal interest or in the interest of their family of other affiliations, but is a demonstrated factor in the decision making of potential candidates. Lawless and Fox note that levels of perceived sexism and fears of hostility, whether realized or not, were strikingly high amongst women considered potential candidates (124). In the Albertan context, MLA Sandra Jansen ended her campaign for leadership of the Progressive Conservative Party of Alberta and crossed the floor to the provincial NDP, stating specifically that sexist remarks and vandalized nomination forms as well as developing socially conservative policies within the party had driven her away from seeking the leadership role (Giovannetti 2OI6). The trend of violence against women in politics in Alberta not only discourages people like Sandra Jansen from seeking a leadership role but adds a compounding factor that discourages participation in a political climate that has been chilly towards women until very recently.

\section{The Albertan 'Glass Cliff'}

The Alberta legislature made strides towards increased representation of women in the elections between I979 and 1997 but had failed to improve beyond those levels in the years since, barring the most recent provincial election. The political climate for women in Alberta has been historically tenuous outside of electoral politics, as Brenda O’Neill notes that the gender wage gap was larger in Alberta than in any other province, that the improvement of social welfare programs that largely benefit women, such as childcare, had largely been absent from dominant political discourse, and that the government had been explicitly against feminist advocacy in the past (O’Neill 2OI3, 4O). She hypothesizes that this, coupled with the longstanding one-party dominance of the Progressive Conservatives, who have had "one of the poorest records of dominant political parties in the province for nominating women to run in general elections" was to blame for the lack of continual progress (49). This is not to say that no Albertan party had made progress in the nomination of women, as the New Democrat Party had outranked every other major party for their proportion of women in every election since I982. In the 2012 election the NDP nearly reached their voluntary quota of gender parity in nominations, with women as 47 percent of their nominees, surpassing the 25 percent and I3 percent proportions of representation for women amongst nominees of the PCs and Wildrose, respectively (44). The lack of representation of women in Alberta's legislature can be linked to the political dominance of a party that did not seek to formally support the greater representation of women, 
but this is not to say change was impossible. The $2 \mathrm{OI}_{5}$ election marked one of the largest changes in the status of women in formal politics in Alberta, as the women who would come to face marked electoral violence were elected.

In a victory often described as 'the Orange Wave', the provincial New Democrats swept the 2015 election, ending the decades-long rule of the Progressive Conservatives, and electing a record number of women to caucus. The reasons for the end of this political 'dynasty' were varied, with some analysts declaring the results of the election to be a reactionary response to the comfortable elitism of the Progressive Conservatives, and partly due to the campaign skill of Rachel Notley and the provincial NDP (Jones 20I5, 4). The NDP caucus comprised of 47 percent women stands as a Canadian record, and Notley's cabinet appointments followed suit in gender parity, making another Canadian first (Sharpe and Braid 2OI6, I55). Despite the strong majority achieved by the NDP, this rapid political shift did not give rise to discourses of stability or unchallenged governance, as some predicted a difficult road ahead for the inexperienced government faced with economic downturn (Jones, 5). It is notable that much of the harassment experienced by female elected officials followed this political upheaval and shift to the left, as it conforms to both patterns of Canadian political party leadership regarding the selection of women, and larger patterns regarding the selection of women for precarious leadership roles.

The discourse surrounding Rachel Notley's capacity to lead, and the incredible rate of threats against her are issues that have been intensified by wider phenomenon regarding external circumstances that serve to bring the leadership capacities of women into question. Perhaps the most distinctive display of contempt for Notley's leadership came in the context of protests regarding the institution of a carbon tax, attended by federal Conservative Party leadership hopeful Chris Alexander and provincial Wildrose Party leader Brian Jean, which erupted with chants of 'lock her up' towards Rachel Notley (Ross and Muzyka 20I6). The chant originated as a campaign-rallying cry directed against Hillary Clinton during the Republican National Convention of 20I6, mean to gesture to her untrustworthiness and dodged accountability for perceived crimes (Stevenson 20I6). As delineated by Krook, this type of threat serves as a sort of symbolic violence, which encompasses acts meant to "deny women's competence as political actors” $(2 \mathrm{OI} 7,80)$. These attitudes directly demonstrate a rejection of the legitimacy of Rachel Notley's democratically decided premiership. Women who strive for political leadership within Alberta not only have experienced harassment merely due to their participation but also are targeted for unpopular policies and marked as illegitimate political actors. However, some remark that Rachel Notley "had taken office in the toughest circumstances faced by any new premier since... the dark heart of the Great Depression" (Sharpe and Braid 20I6, 47). An analysis of this tension between perceived incompetence and the circumstances of Rachel Notley's somewhat unexpected electoral success proves particularly interesting when analyzed within the larger Canadian context.

Until quite recently, women have not enjoyed a large degree of success as the leaders of major Canadian political parties, and this legacy demonstrates Canadian trends that can impact perceptions of Rachel Notley's leadership. Brenda O’Neill and David K. Stewart examine the circumstances of the selection of women as major party leaders at a federal or provincial level from 1980 to 2005, and their findings paint a pessimistic picture for female political leaders in Canada. Canadian political parties have historically been more likely to choose women to be party leaders if they are on the left of the ideological spectrum, and women hold these positions for less time as compared to their male counterpoints (O'Neill 
and Stewart 2009, $75^{2-53}$ ). The authors also conclude that this shorter tenure can be attributed to the fact that women are much more likely to be granted leadership of weak parties, and that women leaders typically enjoy less electoral success than men. Also remarked upon are the typical framing of women leaders as a novelty, and the tendency of the media to scapegoat women in leadership positions for electoral difficulties that could be attributed equally to a general change in leadership. Notley's election raised her from merely the leader of an incredibly weak left-wing party, to the main political figure of a demonstrably unstable province. It is arguable that this instability left her prone to the same fate as many Canadian women in political leadership, susceptible to each of the ill effects of scapegoating for political difficulties outside of her control. Larger theoretical frameworks attempt to explain this phenomenon and contextualize the sudden upsurge in vitriolic and de-legitimizing treatment.

The circumstances of a woman's selection for a leadership role can frame perceptions of their capacity to lead and can thusly exacerbate the type of harassment seen by Albertan officials. This can be explained by the 'glass cliff' phenomenon, which proposes that women are more likely to be appointed to positions of leadership within organizations that are already experiencing difficulty, and thusly can experience extreme criticism, as they carry the weight of the failure of an organization personally, despite their appointment to the position in previously established times of risk (Ryan and Haslam 2007, 557). One theory as to the cause of the phenomenon is that women in leadership positions can be the face of change and a last 'drastic' resort for struggling organizations (560). Certainly, the discourse around the reasons for NDP success in the 2015 election fit this bill. The context of Rachel Notley's election left her faced with a glass cliff, and she faces incredible opposition veering into harassment and violence as a result. The governing of a province in a time of political divide, upheaval, and economic distress, supported by a caucus of inexperienced elected officials is undoubtedly a difficult task. When compounded with the fact that women have become a dominant force in the government of a province historically unripe for the expansion of women's political representation, an ideal environment for gendered electoral violence has been created as ideologically differing members of the polity seek to express extreme frustration with those in power, a face that has only recently been equally female.

\section{Conclusion}

The solution to an environment which threatens to normalize a standard of violence is not clear, but many other states and non-state actors have taken substantive action to limit violence than discourages the political participation of women. Mona Lena Krook discusses some of these strategies, such as internal commitments of party members to eject perpetrators of violence of any form, the influence of public campaigns such as the U.K's "Reclaim the Internet", and even formal legislation to monitor, educate against, or even criminalize violence against women in the political sphere (2OI7, 85-86). Political leaders across the spectrum of Albertan politics have denounced many of the instances of violence against women in the political sphere discussed above (See Ross and Muzyka 2or6, Giovannetti 20I6). Additionally, the Government of Alberta has launched an initiative entitled "Ready for Her", a comprehensive guide to encourage women to run for municipal office. The web page built as the hub for this program acknowledges the influence of Alberta's political culture on desires to run for office, and delineates the importance of women's representation ("Ready for Her", 2OI7). This is a welcome advancement fittingly put forth by the most representative government for women in Canadian history. 
The most recent Albertan election was a watershed moment for the representation of women in formal politics, but the political climate and context of the success of these women, as well as traditionalist views of politics that precipitate all electoral violence left them incredibly susceptible to extreme levels of abuse. This violence threatens progress in representation, as a culture of sexism and fear not only attempts to limit the participation of currently elected officials and question their legitimacy but also discourages women from stepping forward as candidates and continuing the work of making government more representative of the electorate. Factors in the Canadian context, as well as the historical and contemporary realities of political life in Alberta worsen this violent reaction, but the continued work of elected officials and conscious efforts to stand in solidarity against electoral violence can work to prevent its normalization. As a young Albertan woman who studies politics, I am continually critical and hopeful about both the health of our democracy and the willingness of people who represent me to participate, which provides a drive for continued study of the factors influencing women's formal representation. 


\section{References}

Bardall, Gabrielle. 20I3. "Gender-Specific Election Violence: The Role of Information and Communication Technologies." Stability: International Journal of Security and Development 2(3): 6o, pp.I-II, DOI: http://doi.org/IO.5334/sta.cs

Giovannetti, Justin. 20I6. "Alberta Tory MLA Sandra Jansen Defects to NDP, Citing Sexism and Personal Attacks." The Globe and Mail, November I8. http://www.theglobeandmail.com/news/alberta/former-alberta-tory-leadership-candidate-sandrajansen-crosses-floor-to-ndp/article32902968/

Government of Alberta. "Ready for Her.", accessed April ıo, 20I7, https://www.alberta.ca/ready-for-her.aspx.

Jones, David T. 20I5. "Death of a Dynasty: Tory Defeat in Alberta." American Diplomacy: 20-25. Political Science Complete, EBSCOhost.

Krook, Mona Lena. 20I7. "Violence Against Women in Politics." Journal of Democracy 28 (I): 74-88. DOI: https://doi.org/IO.I353/jod.20I7.0007

Lawless, Jennifer L. and Richard L. Fox. 20Io. It Still Takes a Candidate: Why Women Don't Run for Office. Rev ed. New York: Cambridge University Press.

O’Neill, Brenda. 20r3. "The Alberta Advantage? Women in Alberta Politics." In Stalled: The Representation of Women in Canadian Governments, edited by Linda J. Trimble, Jane Arscott, and Manon Tremblay, 36-54. Vancouver: UBC Press.

O’Neill, Brenda and David K. Stewart. 2009. "Gender and Political Party Leadership in Canada." Party Politics I5 (6): 737-757. DOI: $10.1177 /$ I354068809342526

Ross, Andrea and Kyle Muzyka. 20I6. "Albertans Chant 'Lock Her Up' about Rachel Notley at Rally Against Carbon Tax." CBC News, December 4. http://www.cbc.ca/news/canada/edmonton/chris-alexander-lock-her-up-chant-anti-carbon-taxI.38809II

Ryan, Michelle K. and S. Alexander Haslam. 2007. "The Glass Cliff: Exploring the Dynamics Surrounding the Appointment of Women to Precarious Leadership Positions." Academy of Management Review 32(2): 549-572. DOI:IO.5465/AMR.2007.24351856.

Sharpe, Sydney and Don Braid. 2016. "Math is Difficult." In Notley Nation: How Alberta's Political Upheaval Swept the Country, I56-I85. Toronto Ontario: Dundurn. http://deslibris.ca.login.ezproxy.library.ualberta.ca/ID/45II66

Stevenson, Peter W. 20I6. “A Brief History of the 'Lock her up!' Chant by Trump Supporters Against Clinton.” The Washington Post, November 22. https://www.washingtonpost.com/news/the-fix/wp/20I6/II/22/a-brief-history-of-the-lock-her-upchant-as-it-looks-like-trump-might-not-even-try/?utm_term=.a7d3c404b8f6

Trynacity, Kim. 2017. "Rachel Notley: Alberta's Most Threatened Premier." CBC News, February I4. http://www.cbc.ca/news/canada/edmonton/notley-threats-alberta-history-I.3982226 